\title{
Magnetite Nanoparticles as Effective Adsorbent for Water Purification-A Review
}

\section{Mini Namdeo}

Centre of Excellence-Nanotechnology, Indian Institute of Technology Roorkee, Uttarakhand, India

*Corresponding author: Mini Namdeo, Centre of Excellence-Nanotechnology, Indian Institute of Technology Roorkee, Uttarakhand, India, Tel: 01332285490; E-mail: mini.namdeo@gmail.com

Received date: January 26, 2017; Accepted date: June 06, 2017; Published date: July 20, 2017

Copyright: ( 2017 Namdeo M. This is an open-access article distributed under the terms of the Creative Commons Attribution License, which permits unrestricted use, distribution, and reproduction in any medium, provided the original author and source are credited.

\begin{abstract}
Water contamination by substantial metal particles and natural squanders is one of the major environment issues. Dangerous metal particles like $\mathrm{Hg}, \mathrm{Cr}, \mathrm{Cd}, \mathrm{As}, \mathrm{Pb}, \mathrm{Ur}$, and so forth are superfluous metals and thought to be of extraordinary risk for amphibian life, people, plants and other creature. These dangerous metal particles are specifically surrendered into water by sundry mechanical applications and by other human exercises. Magnetite nanocomposites are very much kenned adsorbents for the reflection of awkwardly substantial metal particles from water. Because of their foremost physiochemical properties, cheap strategy and easy recovery within the sight of outside attractive field make them additionally enrapturing towards water cleaning. This survey fundamentally assesses the potential use of surface built magnetite nano-adsorbents in water sanitization.
\end{abstract}

Keywords: Nanoparticles; Adsorbent; Magnetite; Water purification

\section{Introduction}

Water is the most essential compound on earth for the human exercises. Giving clean water is the prime imperative of the individual for their better well-being. Water contamination is augmenting ecumenical because of the fast amplification of industry, augmentation human populace, residential and agrarian exercises which prompts the life time undermining sicknesses [1]. Contaminants continuing in wastewater incorporate awkwardly heavy metals, inorganic mixes, natural contaminations, and numerous other involute mixes [2-4]. These contaminants surrendering into the earth through wastewater are malicious to people and biological environment. Substantial cumbersome metal particles contamination is getting to be a standout amongst the most serious environment pickles ecumenically [5-8]. It is the most danger difficulty for populace in thick nations [9-13] Keeping in mind the end goal to detoxify awkwardly heavy metals, sundry strategies like photocatalytical oxidation, synthetic coagulants, electrochemical, bioremediation, particle trade pitches, reverse osmosis, and adsorption have been utilized $[14,15]$. Late advances propose that huge numbers of the issues including water quality could be determined or extraordinarily enhanced using nanoparticles, nanofiltration or different items coming about because of the improvement of nanotechnology [16,17]. Nanomaterials have been proposed as effective, cost-adequate and ecological genial contrasting option to subsisting water medicines, from the stances of both asset preservation and natural remediation [18-20]. Utilization of iron oxide predicated nanomaterials is all the more enrapturing for reflection of awkwardly overwhelming metal particles pollution from water due to their considerable elements like moment size, high surface territory, and attractive property [21-26]. Attractive property of iron oxide nanoparticles empowers easy disseverment of adsorbents from the framework and could be reused for further application. Reusability of magnetite predicated nanomaterial prompts a decrementation in the financial weight. This survey assesses the principal properties of magnetite nanomaterials. Also highlights not just the recent advancements in the use of iron oxide nanomaterials for wastewater treatment, yet furthermore crevices which obliged their enormously gigantic scale field application. Further the recent improvements on the use of magnetite polymer composite nanomaterials for the cleansing of defiled water is introduced.

\section{Magnetite nanocomposites}

Magnetite $\left(\mathrm{Fe}_{3} \mathrm{O}_{4}\right)$, maghemite $\left(\gamma-\mathrm{Fe}_{2} \mathrm{O}_{3}\right)$, and hematite $\left(\alpha-\mathrm{Fe}_{2} \mathrm{O}_{3}\right)$ are the most prevailing types of iron oxide $[27,28]$. As of late, the amalgamation and usage of iron oxide nanocomposites with novel properties and capacities have been broadly considered, because of their size in nano-range, high surface region to volume proportions and super paramagnetism [29-31]. Solidly, the effortless amalgamation, covering or change, and the workforce to control or control matter on a nuclear scale could give unparalleled attractive minutes [32,33]. Supplementally, magnetite nanocomposites with low lethality, substance idleness and biocompatibility demonstrate an enormous potential in cumulation with biotechnology [34-38]. It is accounted for that readiness techniques and surface covering mediums assume a key part in deciding the size appropriation, morphology, attractive properties and surface science of nanomaterials $[39,40]$. Numerous scientists have been centering their endeavors on creating synthetic and physical techniques for the amalgamation of magnetite nanocomposites [41]. Recently, an assortment of amalgamation methodologies have been produced to incite top notch nanostructures [42] like, nano-ovals [43], nanobelts [44] and nanorings [45] or different nanostructures. Others strategies to amalgamation magnetite nanocomposites are depicted in Table 1.

To comprehend the manner of colloidal iron oxide particles and to enhance their application, carefully think about related to their steadiness is mandatory. Iron oxide nanoparticles are easily subject to conglomeration in watery and natural framework. Magnetite nanoparticles display the hydrophilic surface because of nearness of hydroxyl gatherings. There is a hydrophilic cooperation between 
Citation: Namdeo M (2017) Magnetite Nanoparticles as Effective Adsorbent for Water Purification-A Review. Adv Recycling Waste Manag 2: 135. doi:10.4172/2475-7675.1000135

Page 2 of 13

particles. These particles agglomerate to make cosmically colossal

nanoparticles, there ought to be a harmony amongst charming and bunches. With a specific end goal to have steadiness among unpleasant power acting between these particles [62].

\begin{tabular}{|c|c|c|c|}
\hline Method & Synthesis details & Advantage & References \\
\hline Microemulsion & $\begin{array}{l}\text { Iron salt and base solution are commixed to } \\
\text { disperse in oil phase by integrating surfactant }\end{array}$ & $\begin{array}{l}\text { Diversity of magnetite nanoparticles is } \\
\text { processed by varying the nature and } \\
\text { concentration surfactant and reaction condition }\end{array}$ & {$[46-48]$} \\
\hline Polyols method & $\begin{array}{l}\text { Iron salt solvent dissolves in the polyols solvent. } \\
\text { The suspension is whisked and boiled. Polyols } \\
\text { act as reducing as well as stabilizer }\end{array}$ & $\begin{array}{l}\text { Control of particle magnification, aversion of } \\
\text { interparticle aggregation and obtaining well- } \\
\text { defined morphology of particles }\end{array}$ & {$[49-51]$} \\
\hline Sonolysis & $\begin{array}{l}\text { Organometallic precursors are decomposed by } \\
\text { sonolysis }\end{array}$ & High magnetization and crystallinity is attained & {$[52-54]$} \\
\hline Gas-aerosol & $\begin{array}{l}\text { Ferric salts and a reducing agent in organic } \\
\text { solvent are sprayed into a series of reactors and } \\
\text { aerosol solute compresses and dissipation of } \\
\text { solvent occurs }\end{array}$ & $\begin{array}{l}\text { Different size and shape of particles are framed } \\
\text { by using different iron precursors }\end{array}$ & [55-57] \\
\hline Sol-gel & $\begin{array}{l}\text { Hydroxylation and condensation of molecular } \\
\text { precursors in solution are kenned as "sol," while } \\
\text { evaporation of solvent to compose three- } \\
\text { dimensional network of nanoparticles is called } \\
\text { "gel" }\end{array}$ & $\begin{array}{l}\text { Control of particles size and stability of particles } \\
\text { in sol-gel matrix }\end{array}$ & {$[58]$} \\
\hline Electrochemical decomposition & $\begin{array}{l}\text { Iron oxide nanoparticles engendered by } \\
\text { oxidation of iron electrode in aqueous solution }\end{array}$ & $\begin{array}{l}\text { Particles size control by modifying current } \\
\text { density }\end{array}$ & [59-61] \\
\hline
\end{tabular}

Table 1: Various chemical methods for the synthesis of magnetite nanoparticles.

To surmount this scrape, there is an essential of electronic and steric strength of magnetite nanoparticles. Nearness of hydroxyl gatherings on the surface of these particles gives a diverse manufactured actualize to append distinctive functionalities. Surface alteration techniques of magnetite nanoparticles enhanced the strength and give novel properties to materials. Divergence of analytes by applying outside attractive field and effortless recovery procedure of magnetite nanoparticles for further utilize, makes it cost adequate and effective strategy in reflection of awkwardly heavy metals from water (outwardly see Figure 1).

By and large, nanomaterials ought to be steady to avoid conglomeration and bless a low deposition rate, keeping in mind the end goal to guarantee their reactivity and versatility [64-66]. In any case, it is accounted for that nanomaterials slope to total in arrangement [67]. Regularly, the strength of colloidal nanoparticles is affected by the electrostatic and van der waals collaborations [68]. One spellbinding potential methodology is the change of nanomaterials predicated on the way that magnetite nanomaterials could respond with various practical gatherings. The usage of stabilizer, electrostatic surfactant, and steric polymers has been broadly proposed for encouraging nanomaterials with non-solid moieties, group concrete or highly categorical ligands [69-72].

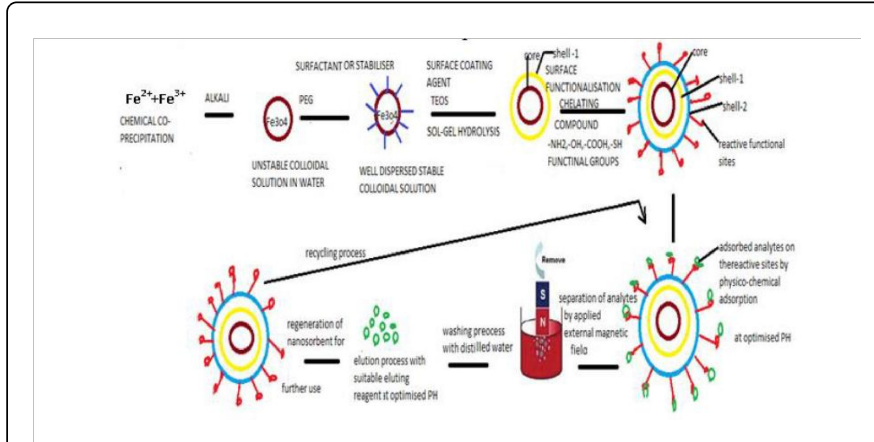

Figure 1: Schematic diagram shows the synthesis, surface fictionalization, application and regeneration of magnetite nanoparticles in extraction of toxic metals [63].

There are a few distinct techniques that have been accounted for creation of iron oxide nanoparticles. Extension of alkoxysilane to the surface of magnetite nanoparticles using diverse silane coupling specialists is the most common surface change method. Organosilane is an enthralling reagent for surface alteration of nanoparticles in view of an effortless business accessibility. By using this reagent, a basic engineered technique is proposed to immobilize on the surface of nanoparticles which gives assortment of usefulness [73-75]. Si-OR gathering of silane responds with surface hydroxyl gathering of magnetite nanoparticles. Trialkoxy profits to present sundry utilitarian gatherings, for example, amine, azide, aldehyde, thio, halide, hydroxyl, and corrosive on the surface of magnetite nanoparticles. Silane coupling operator further gives diverse executes to append little natural atoms, polymers, and biomolecules to the surface. The surface of magnetite nanoparticles alters by PEG (poly-ethyl-glycol) using APS (3aminopropyltriethoxisilane) [76]. 
Oleic corrosive on the surface of magnetite nanoparticles is superseded by biocompatible silane PEG polymer for attractive reverberation imaging of murine tumors [77]. The surface modification of attractive nanoparticles by covering with silica [78]. Because of hydrophilic nature, nanoparticles can effortlessly total. Vinyltriethoxysilane goes about as a coupling operator, which gives hydrophobicity to the surface of magnetite nanoparticles and abatements their agglomerations [78]. Cyanoethyl triethoxysilane is immobilized on the surface of magnetite. Cyano bunch at first glance balances out the magnetite nanoparticles and withal revises the cell marking and the cell focusing on [79]. Click chemistry is moreover an important strategy to alter iron oxide nanoparticles. Click reactions, for example, azide-alkyne, thio-ene, thio-yne, and diels-birch are used for adjustment of the surface of attractive nanoparticles. Oligonucleotides are immobilized on the surface of SPINOs (Super paramagnetic iron oxides nanoparticles). Azide-alkyne copper intercedes click reactions between oligonuclotides bearing alkyne with NHSester reagent and azide practical gathering on the surface of SPINOs. Surface of SPINOs adjusts by copolymers of poly(glycidyl methacrylate) and poly(ethylene glycol) methyl ether methacrylate using iota exchange free radical polymerization (ATRP) and presents folic corrosive (FA) through azide-alkyne click reaction and they balance out in the water to extend in vivo dissemination time [80].

\section{Characterization of Magnetite Nanoparticles}

Distinctive methods are extensively utilized as a part of the written work for magnetite nanoparticle depiction and surface determination i.e., Transmission Electron Microscopy (TEM), Scanning Electron Microscopy (SEM), Fourier Transform Infrared spectroscopy (FTIR), Powder X-shaft Diffraction (XRD) Technique, Atomic Absorption Spectroscopy (AAS), Gel Permeation Chromatography (GPC), Differential Scanning Calorimetry (DSC), Thermogravimetric Analysis (TGA) and Electrical Conductivity Quantification.

Among the sundry strategies utilized for the determination of the atom size and size scattering of nanoparticles, a couple are important in sundry compound circumstances, i.e., minuscule edge X-shaft dispersing (SAXS) and component light scattering (DLS). One particular purpose of enthusiasm of SAXS is that it can be habituated to separate scatterings and likewise powders, however DLS is constrained to debilitate courses of action. Differentiating SAXS and a photo guided system like transmission electron microscopy (TEM), SAXS benefits by a higher authentic quality in the size course innovation giving information about vital particles and aggregates from a single dispersing test. Supplementally, no high vacuum is required, which controls the case to solid state tests. TEM has its strong points of interest as it appropriates direct pictures and local information on morphology and stage present of nanoparticles. In this way, these two frameworks are correlative and cumulating both procedures can provoke preferred information with deference over shape and size of nanoparticles in scatterings or powders [81].

Figure 2 includes a portion of the imperative attributes of magnetite nanoparticles like the size and state of nanoparticles by FE-SEM and TEM (Figures 2a and 2c), which demonstrates that nanoparticles are accumulated to each other amid the drying procedure in readiness. The high-amplification SEM picture (Figure 2b) and TEM picture (Figure 2c) demonstrate that the nanocrystals are generally circular and their sizes are sensibly uniform, extending from 10 to $16 \mathrm{~nm}$ in measurement. The XRD diffraction design in Figure 2e demonstrates six trademark $2 \theta$ tops $30.1^{\circ}, 35.5^{\circ}, 43.1^{\circ}, 53.4^{\circ}, 57.0^{\circ}$ and $62.6^{\circ}$, which are doled out to the (220), (311), (400), (422), (511) and (440), hkl value estimations of magnetite stages.

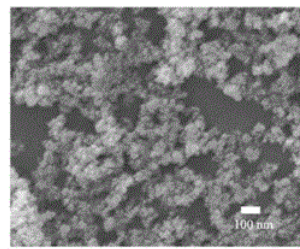

A

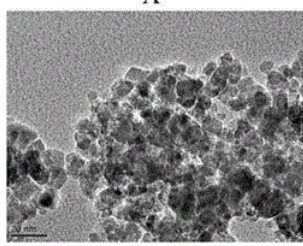

C

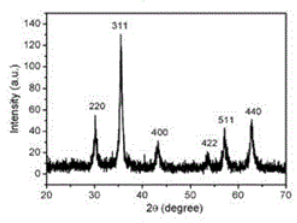

$\mathrm{E}$
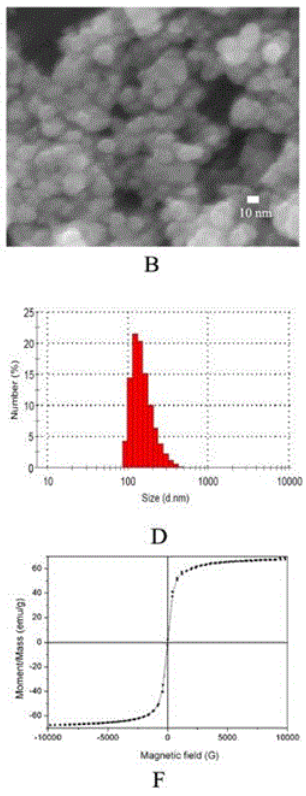

Figure 2: Characterization of Magnetite nanoparticles, (A) lowmagnification SEM and (B) high-magnification SEM; (C) TEM; (D) Particle size distribution; (E) XRD pattern; and (F) Magnetic hysteresis curve [82].

Along these lines the subsequent nanoparticles ought to have superparamagnetic conduct. The hydrodynamic size of magnetite is assessed by DLS. Figure $2 \mathrm{~d}$ demonstrates that the zenith of the hydrodynamic width of magnetite nanoparticles is situated at $155 \mathrm{~nm}$. Plot of polarization versus outer attractive field at $300 \mathrm{~K}$ for the magnetite is appeared in Figure 2f. The immersion polarization is 68:6 $\mathrm{emu} / \mathrm{g}$, which is commensurable with reported magnetite nanoparticles of a related size and a run of the mill attributes of superparamagnetic deportment are demonstrated by the close to zero coercivity and remanence.

\section{Magnetite Nanoparticles as an Effective Adsorbent}

Nano materials are to a great degree solid as a uniqueness medium for water purifying as they contain different key physico-engineered properties, for instance, high surface region to mass extent in view of decremented size of materials (nm estimation) that prompts the availability of a hugely giant number of iotas or atoms at first look to update the adsorption of contaminants [83]. Certain electronic and synergist properties associated with humble size and sizably voluminous surface zone give astounding opportunities to develop more viable water refinement catalysts and redox dynamic media.

Nanomaterials can withal be functionalized with different creation utilitarian social events to make them target particular and cement for different contaminants. Utilizing nanomaterials as a water disinfecting system give less waste instigated after the treatment as proximately all adsorbent particles or atoms on infinitely colossal surfaces are viably utilized for adsorption. Nanomaterials especially got from iron oxides $\left(\mathrm{Fe}_{3} \mathrm{O}_{4},-\mathrm{Fe}_{2} \mathrm{O}_{3}\right)$ show an enormous potential in water purging 
associated with its exceptional traits like low noxious quality, compound dormancy, biocompatibility and super paramagnetism [84].

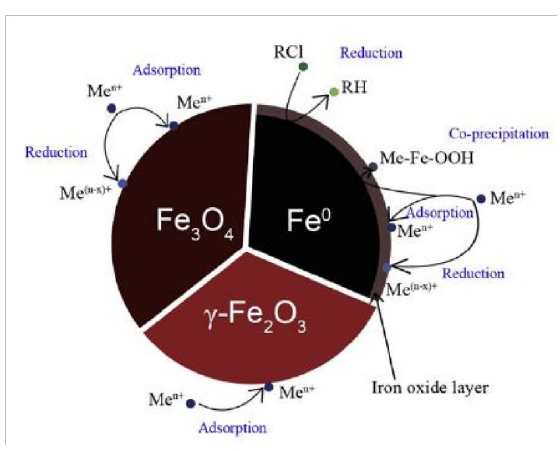

Figure 3: Schematic model represents the core of magnetic nanoparticles mainly provides the power to reduce contaminants. It also provides sites for sorption [85].

Various procedures are accessible for abstracting awkwardly overwhelming metals from waste water including warm, natural and chemical techniques, for example, coagulation, substance precipitation, dissolvable extraction, electrolysis, ultrafiltration film disseverment, and adsorption, light and electro dialysis. Yet, sorption strategies including adsorption and particle trade are potential options for waste water purging. Adsorption is a procedure where a substance (adsorbate) fastens (adsorbs) to another substance (adsorbent) by physical and concoction associations. Sorbate must diffuse from water or gas stage onto the sorbent surface and every now and again into the inside pore of sorbent (Figure 3).

The competency of Magnetite nanomaterials (MNMs) to digest contaminants has been exhibited at both research facility and field scale tests. Momentum uses of MNMs in tainted water treatment can be separated into two gatherings: (an) advancements which use MNMs as a sort of nanosorbent for the reflection of overwhelming massive metal particles and (b) MNMs as photocatalysts to separate or to change over natural contaminants into a less lethal $[86,87]$.

\section{Removal of Arsenic Metal Ion}

Water debasement by arsenic salt is one of the immensely titanic natural pollution. It causes life time ailments, for instance, ailment, neurological perplexity, squeamishness, hyperkeratosis, strong impuissance, and various others [88]. Arsenic polluting in swallowing water has been found locally which can be coordinated to different contaminations. It was represented by world prosperity relationship in 2006 that around 45-57 million people in Bangladesh and 13 million people in Amalgamated States have been exhibited to hazardous arsenic sullied water [89]. As indicated by guidelines of USEPA, most noteworthy contaminant level of arsenic in the splashing up water should be $0.010 \mathrm{ppm}$ [90]. It is thus important to have a strong system to process arsenic from the normal water and waste water. Magnetite nanoparticles have demonstrated discernible result for sanitization of arsenic from the dihydrogen monoxide [91-93]. So, they could get the opportunity to be cost-strong materials for cleaning of arsenic from the water. The minute size and high surface region of magnetite nanoparticles make them flawless adsorbent. Ponderously overpowering metals in the game plan easily diffuse on the dynamic surface of $\mathrm{Fe}_{3} \mathrm{O}_{4}$ nanoparticles. Surface scope of appealing nanoparticles accept a focal part in the adsorption strategy. The high surface nanoparticles can essentially encounter aggregation in the course of action which could decrement their viability so it is key to modify the surface of magnetite nanoparticles for upgrading their development. Surface of iron oxides nanoparticles can be balanced by the expansion with perfect utilitarian get-togethers, for instance, carboxylic acids, phosphoric destructive, silanol, thio, and amine and also minute common particles, biomolecules, polymer, and other metal nanoparticles. Supermagnetic ascorbic destructive secured $\mathrm{Fe}_{3} \mathrm{O}_{4}$ by watery procedure. These nanocomposites have a broadness under 10 $\mathrm{nm}$ and surface zone around $179 \mathrm{~m}^{2} / \mathrm{g}$ [94]. The ascorbic destructive secured $\mathrm{Fe}_{3} \mathrm{O}_{4}$ exhibits super paramagnetic property at room temperature and submersion polarization approaches $40 \mathrm{emu} / \mathrm{g}$ and they are used as an adsorbent to process arsenic from the waste water. The most amazing adsorption farthest point of $\mathrm{As}(\mathrm{V})$ and As (III) is $16.56 \mathrm{mg} / \mathrm{g}$, and $46.06 \mathrm{mg} / \mathrm{g}$, independently, as took after by Langmuir isotherm [94]. Advancement of $\mathrm{Fe}_{2} \mathrm{O}_{3}$ nanoparticles in the system of cellulose has been represented by one pot creation co-precipitation technique [95]. The surface region of these nanocomposites is 113 $\mathrm{m}^{2} / \mathrm{g}$. They are shown for the consideration of arsenic from watery course of action. They demonstrated splendid adsorption capacity to process $\mathrm{As}(\mathrm{III})$ and $\mathrm{As}(\mathrm{V}) 23.16,32.11,9.64$, and $3.25 \mathrm{mg} / \mathrm{g}$ took after by Langmuir and Freundlich isotherm, independently. Cyclodextrin $(\mathrm{CM} \beta \mathrm{CD})$-monodisperse magnetite nanoparticles with typical nanoparticles size $10 \mathrm{~nm}$ are yare by warm decay and post joining technique [96]. These $\mathrm{CMCD}-\mathrm{Fe}_{3} \mathrm{O}_{4}$ are acclimated to remediate of $\mathrm{As}(\mathrm{III}), \mathrm{As}(\mathrm{V}), 2$-naphthol, and naphthalene. $\mathrm{Fe}_{2} \mathrm{O}_{3}$ mid-area nut-like amorphous focus/-stage shell different leveled nanostructure that showed the mind-boggling adsorption of $\mathrm{As}(\mathrm{V})$. It adsorbed 143.12 $\mathrm{m}^{2} / \mathrm{g}$ of $\mathrm{As}(\mathrm{V})$ [97]. The combination of half and half attractive nanoparticles (HMNPs) that were orchestrated as iron oxide invigorated on the winnowed multiwalled carbon nanotubes (MWCNT's- $\mathrm{Fe}_{3} \mathrm{O}_{4}$ ) gotten from MWCNT's oxidized with $\mathrm{HNO}_{3}$. These HMNP's are used for arsenic reflection from groundwater. The adsorption procedure variables are streamlined (centralization of nanoparticles, contact time, and $\mathrm{pH}$ ), and these frameworks could extract $39.93 \mathrm{mg}$ As/g adsorbent. Therefore, these nanoparticles show up as a decent option for abstracting arsenic from debased water tests [98].

\section{Removal of Copper Metal Ion}

Copper has enormous mechanical applications. It is used in the electroplating, paint and shade industry, electrical, and compost. Because of extensive variety of use of copper can be amassed in the earth which makes water more dirty. For the deliberation of copper magnetite nanoparticles surface is changed by ligand 1; 6-hexadiamine [99]. The balance is accomplished inside five minutes and energy took after the pseudo second request component. The most extreme adsorption limit is observed to be $25.77 \mathrm{mg} / \mathrm{g}$ at $\mathrm{pH} 6$ and $298 \mathrm{~K}$.

Amine utilitarian gathering furthermore immobilized on the surface of silica covered attractive nanoparticles by 3aminopropyltriethoxysilan using sol-gel strategy. The adsorption limit of attractive nanoparticles that display amine gathering is $22.4 \mathrm{mg} / \mathrm{g}$ [100]. Banerjee and Chen reported $\mathrm{Fe}_{3} \mathrm{O}_{4}$-gum-arabic nanocomposite for the consideration of $\mathrm{Cu}$ (II) [101]. Gum Arabic (GA) is connected to surface of $\mathrm{Fe}_{3} \mathrm{O}_{4}$ by method for coupling between surface hydroxyl social event of nanoparticles and carboxylic destructive get-together of GA. The ordinary widths of particles are in the extent of 13-67 nm and $5.1 \mathrm{wt} \%$ of arabic gum is immobilized. The adsorption rate is so brisk and agreement is proficient inside 2 minutes. It demonstrated that 
substance adsorption happens and incredible complexation amongst $\mathrm{Cu}(\mathrm{II})$ and amine gathering of arabic gum is created. The zeta potential quality augmented with abatement in $\mathrm{pH}$ of arrangement because of protonation of hydroxyl gathering of nanoparticles and carboxylic corrosive and amine gatherings of GA. The impact of $\mathrm{pH}$ on adsorption is furthermore examined at $\mathrm{pH}<2$ no adsorption occurred. From $\mathrm{pH}$ 2-6 adsorption increments with expansion in $\mathrm{pH}$. The adsorption limit of attractive nanoparticles and GAMNP is 17.6 and $38.5 \mathrm{mg} / \mathrm{g}$, separately, which is taken after Langmuir isotherm. GAMNP recovered by using corrosive arrangement. The GAMNP displays great reusability. The adsorption limit of GA-MNP was 28.12, 27.64, and $27.18 \mathrm{mg} / \mathrm{g}$ in to start with, second, and third adsorptiondesorption cycles, individually [101]. Chitosan covered maghemite nanoparticles were changed with a biodegradable and eco-friendly reagent $a$-ketoglutaric corrosive and showed for reflection of $\mathrm{Cu}$ (II) from water [102]. The adsorption information indicated taking after Langmuir isotherm and most extreme limit of $\mathrm{Cu}(\mathrm{II})$ deliberation were $96.15 \mathrm{mg} / \mathrm{g}$. The impact of $\mathrm{pH}$ and temperature was withal illustrated. The adsorption limit increments with expansion in $\mathrm{pH}$ [103]. Attractive composite microspheres heading of $\mathrm{Fe}_{3} \mathrm{O}_{4}$ nanoparticles and polyacrylic corrosive chitosan (CS/PAA) were yare by synthetic coprecipitation technique as an effective adsorbent for reflection of $\mathrm{Cu}$ (II) [104]. The CS/PAA- $\mathrm{Fe}_{3} \mathrm{O}_{4}$ microspheres have been displayed higher adsorption limit than $\mathrm{CS}-\mathrm{Fe}_{3} \mathrm{O}_{4}$ microspheres. The $\mathrm{Fe}_{3} \mathrm{O}_{4}$ polyvinyl acetic acid derivation iminodiacetic corrosive contains EDTA and was furthermore auxiliary adsorbent for reflection of $\mathrm{Cu}$ (II) [105]. Carboxymethyl--cyclodextrin changed with magnetite nanoparticles $\left(\mathrm{CM} \beta C D-\mathrm{Fe}_{3} \mathrm{O}_{4}\right)$ are the effective attractive adsorbents for the detoxification of copper particles from the water. CMCD joined on the surface of attractive nanoparticles via carbodiimide strategy. The high proficiency of this attractive adsorbent is because of the nearness of numerous hydroxy and carboxyl gatherings. The adsorption of $\mathrm{Cu}(\mathrm{II})$ onto $\mathrm{CM} \beta \mathrm{CD}-\mathrm{MNPs}$ is observed to be subject to $\mathrm{pH}$ and temperature [106].

\section{Removal of Chromium Metal Ion}

Chromium, which is a standout amongst the most lethal metals, is commixed into river stream and ground water through the electroplating businesses, metal finishing, cowhide tanning and chrome plating. In the Coalesced States, it is the second most ordinary inorganic contaminant in waters after lead [107]. Chromium subsists generally in two valence states, in particular $\mathrm{Cr}$ (III) and $\mathrm{Cr}$ (VI), out of which the $\mathrm{Cr}$ (VI) is of the considerable worry because of its lethality. The mechanistic cytotoxicity of $\mathrm{Cr}$ (VI) is not perfectly saw, in any case, a monstrously monster number of studies have exhibited that it actuates oxidative anxiety, DNA harm and apoptotic cell demise [108]. Cr (VI) has been accounted for to be in charge of lung disease, chrome ulcer, aperture of nasal septum and mind and kidney harm [109]. The real reason for its intense danger is its fast diffusivity through the skin which empowers it to respond with natural frameworks and harm sundry organs. Natural scientific experts and material researchers have constantly centered their consideration on the advancement of cost-effectual adsorbents which could be abused for the solid reflection of Cr (VI) from fluid arrangement. These incorporate an assortment of sorbents, for example, polysaccharides [110], wood mash [111], cocoa coals [112], sawdust [113], manufactured hydrous stannic oxide [114], cationized ligano-cellulosic materials [115] and so forth.

As of late nanomaterials have gotten extensive consideration because of their humble molecule size, cosmically monstrous surface range, minimal effort and encourage of arrangement. A large number of the applications and hypothetical points of interest of using nanoparticles for disagreements solidly as connected to biomolecular disseverments [116]. A portion of the real points of interest are related to cosmically enormous and controllable surface range, cost-economy, non-lethality, their scattered nature which shuns numerous traditional problems related to stopping and fouling of pressed segment and layers, and so on. The significant points of interest of using magnetite nanomaterials for disseverment processor incorporate their significantly more modest size (i.e., 10nm), high surface range and for all intents and purposes immaterial mass exchange resistance [117]. The high-angle attractive disseverment (HGMS) could recover $98 \%$ water predicated magnetite nanoparticles covered with a bifunctional polymer.

Attractive grapheme nanocomposites are accounted for by one pot warm disintegration technique [118]. It is a productive nanomaterial for reflection of $\mathrm{Cr}(\mathrm{VI})$ from the waste water at low $\mathrm{pH}$. The cosmically colossal immersion charge $(96.3 \mathrm{emu} / \mathrm{g})$ of the orchestrated nanoparticles sanctions speedy divergence of the adsorbent. Reusing procedure is all the more vigorously and monetarily manageable. The altogether lessened treatment time required to extract the $\mathrm{Cr}(\mathrm{VI})$ and the pertinence in treating the arrangements with low $\mathrm{pH}$ makes attractive graphene adsorbent promising for the productive deliberation of largely awkward metals [118]. Montmorillonite sustained $\mathrm{Fe}_{3} \mathrm{O}_{4}$ nanoparticles showed great adsorption limit than $\mathrm{Fe}_{3} \mathrm{O}_{4}$ for deliberation of $\mathrm{Cr}(\mathrm{VI})$ [119]. The high productivity is because of montmorillonite had porosity which gives better scattering of magnetite nanoparticles inside and less conglomeration. The Magnetic nanoparticles braced on organ peel substance by using redox precipitation technique. These nanoparticles have the $20 \times 80 \mathrm{~nm}$ tubular shapes and octahedral precious stones around $20-40 \mathrm{~nm}$. It showed higher adsorption limit than unmodified appealing nanoparticles towards the impression of $\mathrm{Cr}(\mathrm{VI})$ [120]. Magnetitepolypyrrole $\left(\mathrm{Fe}_{3} \mathrm{O}_{4} / \mathrm{PPy}\right)$ composite microspheres have been consolidated utilizing $\mathrm{Fe}_{3} \mathrm{O}_{4}$ microspheres as a compound arrangement under sonication. $\mathrm{Fe}_{3} \mathrm{O}_{4} / \mathrm{PPy}$ have a vigorous adsorption limit for $\mathrm{Cr}(\mathrm{VI})$ with a most compelling adsorption farthest point of around $209.2 \mathrm{mg} / \mathrm{g}$ [121].

\section{Removal of Uranium Metal Ion}

Uranium is imported into groundwater fundamentally from the handling of uranium minerals. Uranium mining, processing, handling, and transfer, all can possibly sully groundwater. In additament, characteristic uranium assembly happens in territories with high common uranium foundation fixations [122]. Uranium is a lethal and radioactive component. Uranyl mixes have a high liking for phosphate, carboxyl, and hydroxyl bunches and yarely amalgamate with proteins and nucleotides to form stable buildings. The skeleton and kidney are the essential destinations of uranium amassing; a little can be found in the liver. The retained uranium quickly enters the circulatory system and structures a diffusible ionic uranyl hydrogen carbonate many sided in balance with a non-diffusible uranyl egg whites involute. In the skeleton, the uranyl particle supersedes calcium in the hydroxyapatite involute of the bone precious stone. When balance is secured in the skeleton, uranium is discharged by pee and dung. Under antacid conditions, the uranyl hydrogen carbonate involute is steady and is also discharged. In any case, when the $\mathrm{pH}$ esteem drops, the involute separates and ties to the cell proteins in the tubular divider. The moiety-life of uranium in the rodent kidney was observed to associate with 15 days, notwithstanding it is extensively more (300-5,000 days) 
in the skeleton $[123,124]$. Magnetite nanoparticles tried for uranium sorption and deliberation from water sources are hematite [125], goethite [126], ferrihydrite [127], and undefined iron oxides [128,129]. By and large, press oxides adsorb uranium proficiently at $\mathrm{pH}$ values correlated to guzzling water treatment i.e., in the $\mathrm{pH}$ range somewhere around 5 and 9 [130]. Sorption isotherms for uranium deliberation onto iron oxy-hydroxides and found that around $0.125 \mathrm{~mol}$ of $\mathrm{U}(\mathrm{VI})$ was dreamy per mole of Fe(III) at harmony $\mathrm{U}(\mathrm{VI})$ centralization of 0.5 $\mathrm{mg} / \mathrm{L}$ without carbonate [131]. The measure of adsorbed U(VI) decremented significantly with increasing carbonate focuses.

\section{Removal of Lead Metal Ion}

Lead is a wellbeing risk for all people, and youngsters and also grown-ups in for all intents and purposes each area of the globe are being presented to risky levels of lead in the earth. Both word related and ecological exposures to lead remain a grave issue in numerous creating and industrializing nations and in some created nations. In Eastern Europe and numerous creating nations, air contamination is the essential wellspring of lead introduction. Be that as it may, in the Cumulated States the real wellsprings of lead introduction have gotten to be tainted soil and water [132]. Notwithstanding the way that water is rarely the essential wellspring of lead presentation for kids the Environmental Auspice Agency assessed in 2007 that on a normal 20 percent of a tyke's aggregate lead introduction can conceivably be ascribed to lead-defiled dihydrogen monoxide. There is right now different approaches to extract lead from water. Some of them are depicted in Table 2 .

\begin{tabular}{|c|c|c|}
\hline Absorbents & $\begin{array}{l}\mathrm{Qmax}(\mathrm{mg} / \mathrm{g}) \\
\mathrm{Pb}^{2+}\end{array}$ & References \\
\hline $\begin{array}{l}\text { Magnetic chitosan } \\
\text { nanocomposites }\end{array}$ & 32.3 & [133] \\
\hline Iron oxide nanoparticles immobilized-sand material & 2.1 & [134] \\
\hline $\begin{array}{l}\mathrm{Al}_{2} \mathrm{O}_{3} \text {-supported iron } \\
\text { oxide }\end{array}$ & 8.2 & [135] \\
\hline $\mathrm{Al}_{2} \mathrm{O}_{3}$-supported iron oxide & 16.9 & [136] \\
\hline Cellulose-iron oxide Nano spheres & 21.5 & [137] \\
\hline
\end{tabular}

Table 2: Maximum adsorption capacity of $\mathrm{Pb}(\mathrm{II})$ ions onto various iron oxide-based adsorbents.

A novel co-precipitation course to get ready attractive nanocomposites of cellulose utilizing 1-butyl-3-methylimidazolium chloride $([\mathrm{Bmim}] \mathrm{Cl}) \mathrm{IL}$ as co-dissolvable for cellulose and iron salt [137]. This strategy is predicated on the competency of ILs to coseparate cellulose and inorganic salt. Some captivating segments are, (i) This procedure is particularly direct and $[\mathrm{Bmim}] \mathrm{Cl}$ can be basically and suitably distracted and reused, (ii) The mix of the monodisperse $\mathrm{g}$ $\mathrm{Fe}_{2} \mathrm{O}_{3}$ NPs with ultra-minute size $(<5 \mathrm{~nm})$ is depleting to finish in other customary co-precipitation methods and its colossally enormous surface region is cheerful for the adsorption of hazardous contaminants and (iii) Cellulose not simply obliged as a satisfactory fixing master to offset iron oxide and prevent atom all out, yet besides controlled the structures and morphology of iron oxide particles.

The alluring nanocomposites showed awesome adsorption adequacy for $\mathrm{Pb}(\mathrm{II})$ and methylene blue differentiated and other reported appealing materials. The adsorption furthest reaches of the alluring nanospheres for the impression of $\mathrm{Pb}(\mathrm{II})$ and methylene blue are seen to be 21.5 and $40.5 \mathrm{mg} \mathrm{g}^{-1}$, separately [137].

\section{Removal of other metal Ions}

Magnetite nanomaterials (MNMs) could emphatically remove an extent of intensely unwieldy metals, including $\mathrm{Pb}^{2+}, \mathrm{Hg}^{2+}, \mathrm{Cd}^{2+}, \mathrm{Cu}^{2+}$ et al., An once-over of functionalized MNMs with their sorption limit qualities is laid out in Table 3. In any case, press oxide-predicated advancement for clumsily overwhelming metal adsorption is still at a reasonably early stage for wide application. It is apperceived that much work is required to impel recognition in the scope of MNMs, and the trading of these materials from examination office to handle scale application incorporates various intricacies. With expanding designs in contaminant reflection treatment, more data of MNMs is required to be open on execution and cost substructure, which can give extra information to infinitely enormous scale mechanical application [138].

\begin{tabular}{|l|l|l|}
\hline Nanosorbents & Functional groups & Heavy metal ions \\
\hline Mesostructured silica & $-\mathrm{NH}_{2}$ & $\mathrm{Cu}(\mathrm{II})$ \\
\hline Magnetic iron-nickel oxide & - & $\mathrm{Cr}(\mathrm{VI})$ \\
\hline Dimer captosuccinic acid & Thiol group & $\mathrm{Hg}(\mathrm{II}), \mathrm{Ag}(\mathrm{I}), \mathrm{Pb}(\mathrm{II}), \mathrm{Cd}(\mathrm{II}), \mathrm{TI}$ \\
\hline Montmorillonite-supported MNPs & $-\mathrm{AlO} ;-\mathrm{SiO}$ & $\mathrm{Cr}(\mathrm{VI})$ \\
\hline $\mathrm{PEl-coated} \mathrm{Fe}_{3} \mathrm{O}_{4} \mathrm{MNPs}$ & $-\mathrm{NH}_{2}$ & $\mathrm{Cr}(\mathrm{VI})$ \\
\hline
\end{tabular}




\begin{tabular}{|l|l|l|l|}
\hline$\delta$-FeOOH-coated $\mathrm{y}-\mathrm{Fe}_{2} \mathrm{O}_{3} \mathrm{MNPs}$ & - & $\mathrm{Cr}(\mathrm{VI})$ & {$[144]$} \\
\hline Humic acid & Carboxylic and Phenolic group & $\mathrm{Hg}(\mathrm{II}), \mathrm{Pb}(\mathrm{II}), \mathrm{Cd}(\mathrm{II}), \mathrm{Cu}(\mathrm{II})$ & {$[145]$} \\
\hline Flower-like iron oxides & - & $\mathrm{As}(\mathrm{V}), \mathrm{Cr}(\mathrm{VI})$ & {$[146]$} \\
\hline dendrimers & Amine group & $\mathrm{Zn}(\mathrm{II})$ & {$[147]$} \\
\hline Hydrous iron oxide $\mathrm{MNPs}$ & - & $\mathrm{As}(\mathrm{V}), \mathrm{Cr}(\mathrm{VII})$ & {$[148]$} \\
\hline $\mathrm{Fe}_{3} \mathrm{O}_{4}$-silica & $\mathrm{Si}-\mathrm{OH}$ & $\mathrm{Pb}(\mathrm{II}), \mathrm{Hg}(\mathrm{II})$ & {$[149]$} \\
\hline m-PAA-Na-coated $\mathrm{MNPs}$ & $-\mathrm{COO}$ & $\mathrm{Cu}(\mathrm{II}), \mathrm{Pb}(\mathrm{II})$ & {$[150]$} \\
\hline Poly-L-cysteine coated $\mathrm{Fe}{ }_{2} \mathrm{O}_{3} \mathrm{MNPs}$ & $-\mathrm{Si}-\mathrm{O} ;-\mathrm{NH}_{2}$ & $\mathrm{Ni}(\mathrm{II}), \mathrm{Pb}(\mathrm{II})$ & {$[151]$} \\
\hline Amino-modified $\mathrm{Fe}_{3} \mathrm{O}_{4} \mathrm{MNPs}$ & $-\mathrm{NH} \mathrm{H}_{2}$ & $\mathrm{Cu}(\mathrm{II}), \mathrm{Cr}(\mathrm{VII})$ & {$[152]$} \\
\hline salicylic acid functionalized silica & Carboxylic group & $\mathrm{Cu}(\mathrm{II}), \mathrm{Cd}(\mathrm{II}), \mathrm{Ni}(\mathrm{II}), \mathrm{Cr}(\mathrm{III})$ & {$[153]$} \\
\hline carboxymethyl- $\beta$ - cyclodextrin & Carboxylic group & $\mathrm{Cu}(\mathrm{II})$ & {$[154]$} \\
\hline (3-aminopropyl) & trimethoxysilane Amine group & $\mathrm{Pb}(\mathrm{II}), \mathrm{Cd}(\mathrm{II}), \mathrm{Cu}(\mathrm{II})$ & {$[155]$} \\
\hline
\end{tabular}

Table 3: Functionalized iron oxide magnetic nanomaterials in heavy metal adsorption.

\section{Removal of Organic Contaminants}

Recent consideration has been coordinated at chemicals that are verifiably unregulated or not usually directed as contaminants but rather can possibly enter the earth and cause known or suspected unfavorable natural and human wellbeing impacts, for example, pharmaceuticals, individual consideration items, surfactants, different modern added substances, and endocrine disruptors, including hormones [156-158]. As indicated by US land overview (USCS), these chemicals are on the whole characterized as developing natural contaminants (EOCs). The nearness of these engineered chemicals in the wastewater or surface water may defile biological communities and surface and drinking water supplies. Late studies have demonstrated that EOCs may have natural impacts and even potential ecotoxicological sways on spineless creatures i.e., fish, green growth, mussels, furthermore human embryonic cells [159-165]. Till today, the greater part of the studies have focused on the event and destiny of EOCs in surface [166-170] and waste water frameworks [171-174]. Notwithstanding, there are just a couple studies are completed on ways to deal with expel EOCs from fluid media. Subsequently, the advancement of advances to evacuate legacy and rising natural contaminants from water is of extraordinary significance. Lately, attractive particles have gotten a great deal of consideration as effective adsorbents in light of the fact that their inalienable superparamagnetic properties make them alluring for attractive field helped partitions [175-178]. Case in point, attractive iron oxides $\left(\mathrm{Fe}_{2} \mathrm{O}_{3}\right.$ and $\left.\mathrm{Fe}_{3} \mathrm{O}_{4}\right)$ have been accounted for as potential adsorbents for the deliberation of toxins from watery media [179-182]. $\mathrm{Fe}_{3} \mathrm{O}_{4}$ empty nanospheres are appeared to be a strong sorbent for red color (with the greatest adsorption limit of $90 \mathrm{mg} / \mathrm{g}$ ) [183]. The immersion charge of arranged nanospheres is seen to be $42 \mathrm{emu} / \mathrm{g}$, which is sufficient for attractive disseverment with a magnet (basic quality at $16.3 \mathrm{emu} / \mathrm{g}$ ) [184]. These demonstrate that MNMs innovation is a novel, promising and alluring option for natural contaminant adsorption.

The surface attributes of the sorbents are imperative to the viability of the adsorption procedure. Since sorption of natural chemicals can be improved by covering of surfactants onto the sorbent, Wang et.al orchestrated attractive for all time kept micelle exhibits (Mag-PCMAs) with a magnetite center and a silica permeable layer that for all time restricts surfactant micelles to the mesopores [185]. The attractive center takes into account quick division of the Mag-PCMAs from arrangement by applying an attractive field. Mag-PCMAs have been connected for the expulsion of hydrophobic mixes [185], normal natural matter [186], and oxyanions [187].

\section{Removal of Organic Waste by Photocatalytic Decomposition}

Magnetite nanomaterials can be a superior than normal photocatalyst holding detectable light. Separated and consistently related $\mathrm{TiO}_{2}$, which basically ingests UV light with wavelengths of $<380 \mathrm{~nm}$ (covering just 5\% of the sunshine based degree) as a consequence of its wide band-opening of $3.2 \mathrm{eV}, \mathrm{Fe}_{2} \mathrm{O}_{3}$ with bandparted of $2.2 \mathrm{eV} \mathrm{[188]}$ is a spellbinding $\mathrm{n}$-sort semiconducting material and a skilled credibility for photodegradation under obvious light condition. The best photocatalytic execution of $\mathrm{MNMs}$ over $\mathrm{TiO}_{2}$ can be credited to expansive time of electron-hole sets through the thin band-opening light (Equation 1) [189].

$$
\mathrm{Fe}_{2} \mathrm{O}_{3}+\mathrm{hv} \rightarrow \mathrm{Fe}_{2} \mathrm{O}_{3}\left(\mathrm{e}_{\mathrm{cb}}^{-}\right)\left(\mathrm{V}^{+} \text {hv }\right)(1)
$$

Different sorts of $\mathrm{Fe}(\mathrm{III})$ oxides have been proposed, for occurrence, $\alpha-\mathrm{Fe}_{2} \mathrm{O}_{3}, \gamma-\mathrm{Fe}_{2} \mathrm{O}_{3}, \alpha-\mathrm{FeOOH}, \beta-\mathrm{FeOOH}$ and $\gamma-\mathrm{FeOOH}$, to worsen basic contaminations and decrease their ruinous tendency as a consequence of updated photocatalysis influence [190]. These MNMs are illustrative of an early approach to manage control the synergist properties of iron oxide for photocatalysis, towards a secured and strong wastewater treatment nanotechnology. An outline is the photodegradation of Congo red (CR) shading $\left(\mathrm{C}_{32} \mathrm{H}_{24} \mathrm{~N}_{6} \mathrm{O}_{6} \mathrm{~S}_{2}\right)$ by iron oxide nanoparticles which are joined by warm vanishing and coprecipitation approach [191]. The best reflection feasibility is $96 \%$ at a size of $100 \mathrm{~nm}$.

The cumulation of metals with iron oxide nanomaterials can extend the imperativeness of oxidation-reduction response, and grade to be a reasonable framework for photocatalytic change [192]. In additament, in light of its thin bandgap, $\mathrm{Fe}_{2} \mathrm{O}_{3}$ can be related as a sensitizer of $\mathrm{TiO}_{2}$ 
photocatalyst $[193,194]$. Electrons in the valence social events of $\mathrm{TiO}_{2}$ are crashed into $\mathrm{Fe}_{2} \mathrm{O}_{3}$ as a consequence obviously of activity of the characteristic field in $\mathrm{Fe}_{2} \mathrm{O}_{3}-\mathrm{TiO}_{2}$ heterojunction. The charge go ahead between the valance get-togethers of $\mathrm{Fe}_{2} \mathrm{O}_{3}$ and $\mathrm{TiO}_{2}$ is seen as a solid methodology to advance photocatalytic action of the relationship, since it results in an incrementation in the electron-hole recombination time $[195,196]$. Beginning late, a novel photograph Fenton-like structure has been set up with the subsistence of iron oxides and oxalate. Iron oxides were basically gone about as a photocatalyst, while oxalic ruinous could be elated to realize electronhole sets. Figure 4 addresses the lucky structure for the obstruction of microorganisms' cell divider by MNPs. The adsorbed appealing nanoparticles limit the smallness, piece film channel, or stunner the layer of living beings. $\mathrm{Fe}^{2+}$, surrendering from engaging nanoparticles, responds with hydrogen peroxide through Fenton's response, influencing $\mathrm{OH}$-radical and making oxidation. Along these lines this property expands the usage of MNPs in impression of normal contaminants from water.

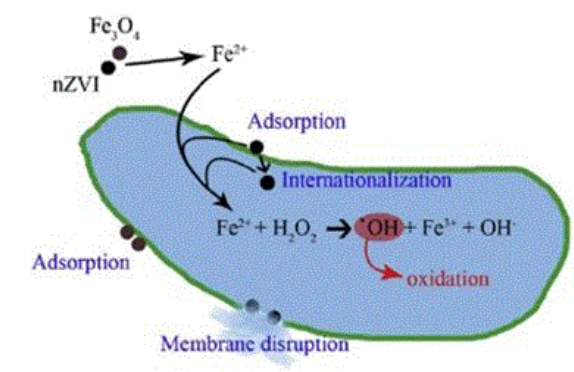

Figure 4: Schematic model represents potential cell damage after exposure of magnetic nanoparticles [85].

\section{Summary}

Wastewater treatment and their reuse is a practice identified with different favorable circumstances as to water equality and organization. The gigantic viability of magnetite nanocomposites to adsorb ponderously solid metals and characteristic poisons from water make them a champion amongst the most stunning and prosperous nanomaterials in the field of water remediation. As a kind of satisfactory photocatalysts, magnetite nanomaterials would show their ascendant preponderation even at a wellspring of unmistakable light. Amalgamation of the predominant adsorption execution and appealing properties of magnetite nanocomposites slant to be a promising approach to manage deal with a collection of natural troubles. Advances in iron oxide NMs could offer opportunities to making forefront adsorption structures with high breaking point, simple disseverment, and delayed lifecycles. The novel physical, mixture and alluring properties of magnetite nanomaterials can support various pushed applications in the change of adsorptive advances, and thusly prompt more capable and cost-sufficient remediation approaches as differentiated and routine advances.

\section{References}

1. Schwarzenbach RP, Egli T, Hofstetter TB, von Gunten U, Wehrli B (2010) Global water pollution and human health. Ann Rev of Environ Resour 35: 109-136.
2. O'Connor GA (1996) Organic compounds in sludge-amended soils and their potential for uptake by crop plants. Sci of the Total Environ 185: 71-81.

3. Fatta KD, Kalavrouziotis IK, Koukoulakis PH, Vasquez MI (2011) The risks associated with wastewater reuse and xenobiotics in the agroecological environment. Sci Total Environ 409: 3555-3563.

4. Li X, Zeng GM, Huang JH, Zhang DM, Shi LJ, et al. (2011) Simultaneous removal of cadmium ions and phenol with MEUF using SDS andmixed surfactants. Desalination 276: 136-141.

5. Fujita M, Ide Y, Sato D, Kench PS, Kuwahara Y (2014) Heavy metal contamination of coastal lagoon sediments: Fongafale Islet, Funafuti Atoll, Tuvalu. Chemosphere 95: 628-634.

6. Al-Musharafi SK, Mahmoud IY, Al-Bahry SN (2013) Heavy metal pollution from treated sewage effluent. APCBEE Procedia 5: 344-348.

7. Naser HA (2013) Assessment and management of heavy metal pollution in the marine environment of the Arabian Gulf: a review. Mari Pollu Bulle 72: 6-13.

8. Akinci G, Guven DE, Ugurlu SK (2013) Assessing pollution in Izmir Bay from rivers in western Turkey: heavy metals. Environ Sci Proc Impac 15: 2252-2262.

9. Zan F, Huo S, Xi B, Su J, Li X, et al. (2011) A 100 year sedimentary record of heavy metal pollution in a shallow eutrophic lake, Lake Chaohu, China. J Environ Monitor 13: 2788-2797.

10. Wang SL, Xu XR, Sun YX, Liu JL, Li HB (2013) Heavy metal pollution in coastal areas of South China: a review. Marine Pollu Bulle 76: 7-15.

11. Li Z, Ma Z, van der Kuijp TJ, Yuan Z, Huang L (2014) A review of soil heavy metal pollution from mines in China: pollution and health risk assessment. Sci Total Environ 468: 843-853.

12. Gowd SS, Reddy MR, Govil PK (2010) Assessment of heavy metal contamination in soils at Jajmau (Kanpur) and Unnao industrial areas of the Ganga Plain, Uttar Pradesh, India. J of Hazard Mat 174: 113-121.

13. Deshpande PC, Tilwankar AK, Asolekar SR (2012) A novel approach to estimating potential maximum heavy metal exposure to ship recycling yard workers in Alang, India. Sci Total Environ 438: 304-311.

14. Friedrich KA, Henglein F, Stimming U, Unkauf W (1998) Investigation of Pt particles on gold substrates by IR spectroscopy particle structure and catalytic activity. Colloid Surf A: Physicochem Eng Aspec 134: 193-206.

15. Dimitrov DS (2006) Interactions of antibody-conjugated nanoparticles with biological surfaces. Colloid and Surf A: Physicochem and Eng Aspec 282: 8-10.

16. Dastjerdi R, Montazer M (2010) A review on the application of inorganic nano-structured materials in the modification of textiles: focus on antimicrobial properties. Colloid Surf B 79: 5-18.

17. Xu P, Zeng GM, Huang DL, Feng CL, Hu S, et al. (2012) Use of iron oxide nanomaterials in waste water treatment: a review. Sci of the Total Environ 424: 1-10.

18. Friedrich KA, Henglein F, Stimming U, Unkauf W (1998) Investigation of Pt particles on gold substrates by IR spectroscopy-particle structure and catalytic activity. Colloids Surf A 134: 193-206.

19. Dimitrov D (2006) Interactions of antibody-conjugated nanoparticles with biological surfaces. Colloids Surf A 282: 8-10.

20. Dastjerdi R, Montazer M (2010) A review on the application of inorganic nano-structured materials in the modification of textiles: focus on antimicrobial properties. Colloid Surf B 79: 5-18.

21. Sun S, Zeng H (2002) Size-controlled synthesis of magnetite nanoparticles. J Amer Chem Soc 124: 8204-8205.

22. Daou TJ, Pourroy G, Bégin-Colin S, Greneche JM, Bouillet CU, et al. (2006) Hydrothermal synthesis of monodisperse magnetite nanoparticles. Chem Mat 18: 4399-4404.

23. Wang J, Peng Z, Huang Y, Chen Q (2004) Growth of magnetite nanorods along its easy-magnetization axis. J Cryst Growth 263: 616-619.

24. Mizutani N, Iwasaki T, Watano S, Yanagida T, Tanaka H, et al. (2008) Effect of ferrous/ferric ions molar ratio on reaction mechanism for hydrothermal synthesis of magnetite nanoparticles. Bulle Mat Sci 31: 713-717. 
25. Du J, Jing C (2011) Preparation of thiol modified Fe3O4@ Ag magnetic SERS probe for PAHs detection and identification. The J Phys Chem C 115: $17829-17835$

26. Chen M, Yamamuro S, Farrell D, Majetich SA (2003) Gold-coated iron nanoparticles for biomedical applications. J App Phys 93: 7551-7553.

27. Cornel RM, Schwertmann U (1996) The Iron Oxides. Structure, Properties, Reactions and Uses.

28. Chan HBS, Ellis BL (2004) Carbon-encapsulated radioactive 99mTc nanoparticles. Adv Mater 16: 144-149.

29. McHenry ME, Laughlin DE (2000) Nano-scale materials development for future magnetic applications. Acta Mater 48: 223-238.

30. Afkhami A, Saber-Tehrani M, Bagheri H (2010) Modified maghemite nanoparticles as an efficient adsorbent for removing some cationic dyes from aqueous solution. Desalination 263: 240-248.

31. Pan BJ, Qiu H, Pan BC, Nie GZ, Xiao LL, et al. (2010) Highly efficient removal of heavy metals by polymer-supported nanosized hydrated Fe(III) oxides: behavior and XPS study. Water Res 44: 815-824.

32. Boyer C, Whittaker MR, Bulmus V, Liu JQ, Davis TP (2010) The design and utility of polymerstabilized iron-oxide nanoparticles for nanomedicine applications. NPG Asia Mater 2: 23-30.

33. Dias AMGC, Hussain A, Marcos AS, Roque ACA (2011) A biotechnological perspective on the application of iron oxide magnetic colloids modified with polysaccharides. Biotechnol Adv 29: 142-155.

34. Huang SH, Liao MH, Chen DH (2003) Direct binding and characterization of lipase onto magnetic nanoparticles. Biotechnol Prog 19: 1095-1100.

35. Roco MC (2003) Nanotechnology: convergence with modern biology and medicine. Curr Opin Biotechnol 14: 337-346.

36. Gupta AK, Gupta M (2005) Synthesis and surface engineering of iron oxide nanoparticles for biomedical applications. Biomaterials 26: 3995-4021.

37. Bystrzejewski M, Pyrzyńska K, Huczko A, Lange H (2009) Carbonencapsulated magnetic nanoparticles as separable and mobile sorbents of heavy metal ions from aqueous solutions. Carbon 47: 1201-1204.

38. Selvan ST, Tan TTY, Yi DK, Jana NR (2010) Functional and multifunctional nanoparticles for bioimaging and biosensing. Langmuir 26: 11631-11641.

39. Jeong U, Teng X, Wang Y, Yang H, Xia Y (2007) Superparamagnetic colloids: controlled synthesis and niche applications. Adv Mater 19: 33-60.

40. Machala J, Zboril R, Gedanken A (2007) Amorphous iron(III) oxides: a review. J Phys Chem B 111: 4003-4018.

41. Hassanjani RA, Vaezi MR, Shokuhfar A, Rajabali Z (2011) Synthesis of iron oxide nanoparticles via sonochemical method and their characterization. Particuology 9: 95-99.

42. Zhong JY, Cao CB (2010) Nearly monodisperse hollow Fe2O3 nanoovals: synthesis, magnetic property and applications in photocatalysis and gas sensors. Sens Actuators B Chem 145: 651-656.

43. Fan HT, Zhang T, Xu XJ, Lv N (2011) Fabrication of N-type Fe2O3 and Ptype $\mathrm{LaFeO} 3$ nanobelts by electrospinning and determination of gassensing properties. Sens Actuators B 153: 83-88.

44. Gotić M, Dražić G, Musić S (2011) Hydrothermal synthesis of $\alpha-\mathrm{Fe} 2 \mathrm{O} 3$ nanorings with the help of divalent metal cations, Mn2+, Cu2+, $\mathrm{Zn} 2+$ and Ni2+. J Mol Struct 993: 167-176.

45. Vidal J, Rivas V, Lopez-Quintela MA (2006) Synthesis of monodisperse maghemite nanoparticles by the microemulsion method. Colloids and Surf A 288: 44-51.

46. Chin AB, Yaacob II (2007) Synthesis and characterization of magnetic iron oxide nanoparticles via w/o microemulsion and Massart's procedure. J Mat Proc Tech 191: 235-237.

47. Han LH, Liu H, Wei Y (2011) In situ synthesis of hematite nanoparticles using a low-temperature microemulsion method. Powder Techn 207: 42-46.
48. Joseyphus RJ, Kodama D, Matsumoto T, Sato Y, Jeyadevan B, et al. (2007) Role of polyol in the synthesis of Fe particles. J Magne and Magnet Mat 310: 2393-2395.

49. Cai W, Wan J (2007) Facile synthesis of superparamagnetic magnetite nanoparticles in liquid polyols. J Colloid and Interf Sci 305: 366-370.

50. Abbas M, Rao BP, Naga SM, Takahashi M, Kim CG (2013) Synthesis of high magnetization hydrophilic magnetite ( $\mathrm{Fe} 3 \mathrm{O} 4)$ nanoparticles in single reaction surfactntless polyol process. Ceram Intern 39: 7605-7611.

51. Qasemand RA, Gedanken A (2005) Sonochemical synthesis of stable hydrosol of Fe3O4 nanoparticles. J Colloid and Interf Sci 284: 489-494.

52. Park SJ, Kim S, Lee S, Khim ZG, Char K (2000) Synthesis and magnetic studies of uniform iron nanorods and nanospheres. J Amer Chem Soc 122: 8581-8582.

53. Kim EH, Lee HS, Kwak BK, Kim BK (2005) Synthesis of ferrofluid with magnetic nanoparticles by sonochemical method for MRI contrast agent. J Magn and Magnet Mat 289: 328-330.

54. Kumfer BM, Shinoda K, Jeyadevan B, Kennedy IM (2010) Gas-phase flame synthesis and properties of magnetic iron oxide nanoparticles with reduced oxidation state. J Aeros Sci 41: 257-265.

55. Li Y, Hu Y, Huang G, Li C (2013) Metallic iron nanoparticles: Flame synthesis, characterization and magnetic properties. Particuol 11: $460-467$

56. Saunders RW, Plane JM (2010) The formation and growth of $\mathrm{Fe} 2 \mathrm{O} 3$ nanoparticles from the photo-oxidation of iron pentacarbonyl. J Aeros Sci 41: 475-489.

57. Cui H, Liu Y, Ren W (2013) Structure switch between - Fe2O3,- Fe2O3 and $\mathrm{Fe} 3 \mathrm{O} 4$ during the large scale and low temperature sol-gel synthesis of nearly monodispersed iron oxide nanoparticles. Adv Powder Techn 24: 93-97.

58. Marques RF, Garcia C, Lecante P, Ribeiro SJ, Noé L (2008) Electroprecipitation of $\mathrm{Fe} 3 \mathrm{O} 4$ nanoparticles in ethanol. J Magne and Magnet Mat 320: 2311-2315.

59. Cabrera L, Gutierrez S, Menendez N, Morales MP, Herrasti P (2008) Magnetite nanoparticles: electrochemical synthesis and characterization. Electrochimica Acta 53: 3436-3441.

60. Fajaroh F, Setyawan H, Widiyastuti W, Winardi S (2012) Synthesis of magnetite nanoparticles by surfactant-free electrochemical method in an aqueous system. Adv Powder Techn 23: 328-333.

61. Laurent S, Forge D, Port M, Roch A, Robic C, et al. (2008) Magnetic iron oxide nanoparticles: synthesis, stabilization, vectorization, physicochemical characterizations, and biological applications. Chem Rev 108: 2064-2110.

62. Neyaz N, Siddiqui WA, Nair KK (2014) Application of surface functionalized iron oxide nanomaterials as a nanosorbents in extraction of toxic heavy metals from ground water: a review. Intern J Environ Sci 4: 472.

63. Schrick B, Hydutsky BW, Blough JL, Mallouk TE (2004) Delivery vehicles for zerovalent metal nanoparticles in soil and groundwater. Chem Mater 16: 2187-2193.

64. Kanel SR, Nepal D, Manning B, Choi H (2007) Transport of surfacemodified iron nanoparticle in porous media and application to arsenic(III) remediation. J Nanopart Res 9: 725-735.

65. Tiraferri A, Chen KL, Sethi R, Elimelech M (2008) Reduced aggregation and sedimentation of zero-valent iron nanoparticles in the presence of guar gum. J Colloid Interf Sci 324: 71-79.

66. Lin CL, Lee CF, Chiu WY (2005) Preparation and properties of poly (acrylic acid) oligomer stabilized superparamagnetic ferrofluid. J Colloid Interf Sci 291: 411-420.

67. Chen KL, Mylon SE, Elimelech M (2007) Enhanced aggregation of alginate-coated iron oxide (hematite) nanoparticles in the presence of calcium, strontium, and barium cations. Langmuir 23: 5920-5928.

68. Hyeon T, Lee SS, Park J, Chung Y, Na HB (2001) Synthesis of highly crystalline and monodisperse maghemite nanocrystallites without a sizeselection process. J Am Chem Soc 123: 12798-12801. 
69. Harris L, Goff J, Carmichael A, Riffle J, Harburn J, et al. (2003) Magnetite nanoparticle dispersions stabilized with triblock copolymers. Chem Mater 15: 1367-1377.

70. Batalha IL, Hussain A, Roque A (2010) Gum arabic coated magnetic nanoparticles with affinity ligands specific for antibodies. J Mol Recognit 23: 462-471.

71. Sung YK, Ahn BW, Kang TJ (2012) Magnetic nanofibers with core (Fe3O4 nanoparticle suspension)/sheath (poly ethylene terephthalate) structure fabricated by coaxial electrospinning. J Magn Magn Mater 324 916-922.

72. Sheng GI, Xiaodong SH, Benlan LI (2006) Surface organic modification of $\mathrm{Fe} 3 \mathrm{O} 4$ nanoparticles by silane-coupling agents. Rare Metals 25: 426-430.

73. Mohammad-Beigi H, Yaghmaei S, Roostaazad R, Bardania H, Arpanaei A (2011) Effect of $\mathrm{pH}$, citrate treatment and silanecoupling agent concentration on the magnetic, structural and surface properties of functionalized silica-coated iron oxide nanocomposite particles. Physica E 44: 618-627.

74. Kango S, Kalia S, Celli A, Njuguna J, Habibi Y (2013) Surface modification of inorganic nanoparticles for development of organicinorganic nanocomposites-a review. Prog in Poly Sci 38: 1232-1261.

75. Barrera C, Herrera AP, Bezares N, Fachini E, Olayo-Valles R (2012) Effect of poly (ethylene oxide)-silane graft molecular weight on the colloida properties of iron oxide nanoparticles for biomedical applications. J Colloid Interf Sci 377: 40-50.

76. Larsen EK, Nielsen T, Wittenborn T, Birkedal H, Vorup-Jensen T, et al. (2009) Size-dependent accumulation of PEGylated silane-coated magnetic iron oxide nanoparticles in murine tumors. ACS Nano 3: 1947-1951.

77. Ahangaran F, Hassanzadeh A, Nouril S (2011) Surfacemodification of Fe3O4@SiO2 microsphere by silane coupling agent. Intern Nano Lett 233: 1-5.

78. Forge D, Laurent S, Gossuin Y, Roch A, Vander EL, et al. (2011) An original route to stabilize and functionalize magnetite nanoparticles for theranosis applications. J Magn and Magnet Mat 323: 410-415.

79. Huang C, Neoh KG, Kang ET (2011) Combined ATRP and 'click'chemistry for designing stable tumor-targeting superparamagnetic iron oxide nanoparticles. Langmuir 28: 563-571.

80. Pabisch S, Feichtenschlager B, Kickelbick G, Peterlik H (2012) Effect of interparticle interactions on size determination of zirconia and silica based systems-A comparison of SAXS, DLS, BET, XRD and TEM. Chem Phy Lett 521: 91-97.

81. Liu Y, Li X, Bao S, Lu Z, Li Q, et al. (2013) Plastic protein microarray to investigate the molecular pathways of magnetic nanoparticle-induced nanotoxicity. Nanotechn 24: 175501.

82. Savage N, Diallo MS (2005) Nanomaterials and water purification: opportunities and challenges. J Nanoparticle Res 7: 331-342.

83. McHenry ME, Laughlin DE (2000) Nano-scale materials development for future magnetic applications. Acta Mat 48: 223-238.

84. Samuel CN, Tang Irene MCL (2013) Magnetic nanoparticles: Essential factors for sustainable environmental applications. Water Res 47: 2613 e2632.

85. White BR, Stackhouse BT, Holcombe JA (2009) Magnetic $\gamma$-Fe2O3 nanoparticles coated with poly-L-cysteine for chelation of $\mathrm{As}(\mathrm{III}), \mathrm{Cu}(\mathrm{II})$, $\mathrm{Cd}(\mathrm{II}), \mathrm{Ni}(\mathrm{II}), \mathrm{Pb}(\mathrm{II})$ and $\mathrm{Zn}(\mathrm{II})$. J Hazard Mater 161: 848-853.

86. Girginova PI, Daniel-da-Silva AL, Lopes CB, Figueira P, Otero M, et al. (2010) Silica coated magnetite particles for magnetic removal of $\mathrm{Hg} 2+$ from water. J Colloid Interf Sci 345: 234-240.

87. Mandal BK, Suzuki KT (2002) Arsenic round the world: a review. Talanta 58: 201-235.

88. An B, Liang Q, Zhao D (2011) Removal of arsenic (V) from spent ion exchange brine using a new class of starch-bridged magnetite nanoparticles. Water Res 45: 1961-1972.

89. https://www.epa.gov/regulatory-information-topic/regulatoryinformation-topic-water
90. Yang W, Kan AT, Chen W, Tomson MB (2010) pH-dependent effect of zinc on arsenic adsorption to magnetite nanoparticles. Water Res 44: 5693-5701.

91. Yavuz CT, Mayo JT, Suchecki C, Wang J, Ellsworth AZ (2010) Pollution magnet: nano-magnetite for arsenic removal from drinking water. Environ Geochem and Health 32: 327-334.

92. Jeong Y, Fan M, Singh S, Chuang CL, Saha B, et al. (2007) Evaluation of iron oxide and aluminum oxide as potential arsenic (V) adsorbents. Chemical Engineering and Processing: Process Intens 46: 1030-1039.

93. Feng L, Cao M, Ma X, Zhu Y, Hu C (2012) Superparamagnetic highsurface-area $\mathrm{Fe} 3 \mathrm{O} 4$ nanoparticles as adsorbents for arsenic removal. J Hazard Mat 217: 439-446.

94. Yu X, Tong S, Ge M, Zuo J, Cao C, et al. (2013) One-step synthesis of magnetic composites of cellulose iron oxide nanoparticles for arsenic removal. J Mat Chem A 3: 959-965.

95. Chalasani R, Vasudevan S (2012) Cyclodextrin functionalized magnetic iron oxide nanocrystals: a host-carrier for magnetic separation of nonpolar molecules and arsenic from aqueous media. J Mat Chem 22: 14925-14931.

96. Mou F, Guan J, Xiao Z, Sun Z, Shi W, et al. (2011) Solvent-mediated synthesis of magnetic $\mathrm{Fe} 2 \mathrm{O} 3$ chestnutlike amorphous-core/-phase-shell hierarchical nanostructures with strong As(v) removal capability. J Mat Chem 21: 5414-5421.

97. Bavio MA, Lista AG (2013) Synthesis and characterization of hybridmagnetic nanoparticles and their application for removal of arsenic from groundwater. The Sci World J.

98. Hao YM, Man C, Hu ZB (2010) Effective removal of $\mathrm{Cu}$ (II) ions from aqueous solution by amino-functionalized magnetic nanoparticles. $J$ of Hazard Mat 184: 392-399.

99. Hui L, Xiao DL, Hua HE, Rui L, Zuo PL (2013). Adsorption behavior and adsorption mechanism of $\mathrm{Cu}$ (II) ions on amino-functionalized magnetic nanoparticles. Transac of Nonfer Metals Soc 23: 2657-2665.

100. Banerjee SS, Chen DH (2007) Fast removal of copper ions by gum arabic modified magnetic nano-adsorbent. J Hazardous Materials 147: 792-799.

101. Zhou YT, Nie HL, Branford-White C, He ZY, Zhu LM (2009) Removal of $\mathrm{Cu} 2+$ from aqueous solution by chitosan coated magnetic nanoparticles modified with ketoglutaric acid. J of Colloid and Interf Sci 330: 29-37.

102. Chang YC, Chen DH (2005) Preparation and adsorption properties of monodisperse chitosan-bound $\mathrm{Fe} 3 \mathrm{O} 4$ magnetic nanoparticles for removal of $\mathrm{Cu}$ (II) ions. J Colloid and Interf Sci 283: 446-451.

103. Yan H, Yang L, Yang Z, Yang H, Li A (2012) Preparation of chitosan/poly (acrylic acid) magnetic composite microspheres and applications in the removal of copper (II) ions from aqueous solutions. J Hazard Mat 229: 371-380.

104. Tseng JY, Chang CY, Chang CF, Chen YH, Chang C, et al. (2009) Kinetics and equilibrium of desorption removal of copper from magnetic polymer adsorbent. J Hazard Mat 171: 370-377.

105. Badruddoza AZM, Tay ASH, Tan PY, Hidajat K, Uddin MS (2011) Carboxymethyl- $\beta$-cyclodextrin conjugated magnetic nanoparticles as nano-adsorbents for removal of copper ions: synthesis and adsorption studies. J Hazardous Mat 185: 1177-1186.

106. Wielinga B, Mizuba MM, Hansel CM, Fendorf S (2001) Iron promoted reduction of chromate by dissimilatory iron-reducing bacteria. Environ Sci Techn 35: 522-527.

107. Namdeo M, Bajpai SK (2008) Investigation of hexavalent chromium uptake by synthetic magnetite nanoparticles. EJEAF Che 7: 3082-3094.

108. Stohs SJ, Bagchi D, Hassoun E, Bagchi M (1999) Oxidative mechanisms in the toxicity of chromium and cadmium ions. J Environ Pathol Toxicol and Oncol 19: 201-213.

109. Namdeo M, Bajpai SK (2008) Investigation of hexavalent chromium uptake by synthetic magnetite nanoparticles. EJEAF Che 7: 3082-3094.

110. Abdel-Halim ES, Abou-Okeil A, Hashem A (2006) Adsorption of Cr (VI) oxyanions onto modified wood pulp. Poly-Plast Techn and Eng 45: 71-76. 
111. Gode F, Pehlivan E (2006) Chromium (VI) adsorption by brown coals. Energy Sour 28: 447-457.

112. Barut D, Korkmaz N, Astley ST, Aygün M (2014) Synthesis, X-ray structural and thermal analysis of a novel copper compound containing dissymmetric independent 5-and 6-coordinate $\mathrm{CuL}(\mathrm{H} 2 \mathrm{O}) \mathrm{n}(\mathrm{n}=2,3)$ units and hydrogen bond bridges. Acta Chimica Slovenica 62: 88-94.

113. Goswami S, Ghosh UC (2005) Studies on adsorption behaviour of $\mathrm{Cr}$ (VI) onto synthetic hydrous stannic oxide. Water SA 31: 597-602.

114. Zghida H, Baouab MHV, Gauthier R (2003) Sorption of chromium oxyanions onto cationized lignocellulosic material. J App Poly Sci 87: 1660-1665.

115. Bucak S, Jones DA, Laibinis PE, Hatton PA (2003) Synthesis of Nanocomposites. Biotechnol Prog 19: 477-484.

116. Ashtari P, Wang K, Yang X, Hwang S, Yamini Y (2005) Removal of Synthetic Hydrous from Wood. Analy Chimica Acta 550: 18-23.

117. Zhu J, Wei S, Gu H, Rapole SB, Wang Q, et al. (2011) One-pot synthesis of magnetic graphene nanocomposites decorated with core double-shel nanoparticles for fast chromium removal. Environ Sci Techn 46: 977-985.

118. Yuan P, Fan M, Yang D, He H, Liu D, et al. (2009) Montmorillonitesupported magnetite nanoparticles for the removal of hexavalent chromium [Cr (VI)] from aqueous solutions. J Hazard Mat 166: 821-829.

119. Lopez-Tellez G, Barrera-Diaz CE, Balderas-Hernandez P, Roa-Morales G, Bilyeu B (2011) Removal of hexavalent chromium in aquatic solutions by iron nanoparticles Embedded in Orange peel pith. Chem Eng J 173: 480-485.

120. Wang Y, Zou B, Gao T, Wu X, Lou S, et al. (2012) Synthesis of orange-like $\mathrm{Fe} 3 \mathrm{O} 4 / \mathrm{PPy}$ composite microspheres and their excellent $\mathrm{Cr}(\mathrm{VI})$ ion removal properties. Journal of Materials Chemistry 22: 9034-9040.

121. Barnett MO, Jardine PM, Brooks SC, Selim HM (2000) Adsorption and transport of uranium(VI) in subsurface media. Soil Sci Soc Am J 64: 908-917.

122. WHO (2005) Uranium in drinking water background document for the development of $\mathrm{WHO}$ guidelines for drinking water quality.

123. Zamora ML, Zielinski JM, Meyerhof DP, Moss MA (1998) Chronic ingestion of uranium in drinking water: a study of kidney bioeffects in humans. Toxicol Sci 43: 68- 77.

124. Bargar JR, Reitmeyer R, Lenhart JJ, Davis JA (2000) Characterization of $\mathrm{U}(\mathrm{VI})$ carbonato ternary complexes on heamatite: EXAFS and electrophoretic mobility measurements. Geochim Cosmochim Acta 64: 2737-2749.

125. Duff MC, Amrhein C (1996) Uranium(VI) adsorption on goethite and soil in carbonate solutions. Soil Sci Soc Am J 60: 1393-1400.

126. Waite TD, Davis JA, Payne TE, Waychunas GA, Xu N (1994) Uranium(VI) adsorption to ferrihydrite: Application of a surface complexation model. Geochim Cosmochim Acta 58: 5465-5478.

127. Katsoyiannis IA, Althoff HW, Bartel H, Jekel M (2006) The effect of groundwater composition on uranium(VI) sorption onto bacteriogenic iron oxides. Water Res 40: 3646-3652.

128. Katsoyiannis IA (2007) Carbonate effects and pH-dependence of uranium sorption onto bacteriogenic iron oxides: Kinetic and equilibrium studies. J Hazard Mater 139: 31-37.

129. Barnett MO, Jardine PM, Brooks SC (2002) U(VI) adsorption to heterogeneous subsurface media: application of surface complexation model. Environ Sci Technol 36: 937-942.

130. Wazne M, Korfiatis GP, Meng X (2003) Carbonate effects on hexavalent uranium adsorption by iron oxyhydroxides. Environ Sci Technol 37: 3619-3624.

131. Herman DS, Geraldine M, Venkatesh T (2007) Evaluation, diagnosis, and treatment of lead poisoning in a patient with occupational lead exposure: a case presentation. J Occup Med Toxicol 24: 7.

132. Liu X, Hu Q, Fang Z, Zhang X, Zhang B (2009) Magnetic chitosan nanocomposites: a useful recyclable tool for heavy metal ion removal. Langmuir 25: 3-8.
133. Lee S, Laldawngliana C, Tiwari D (2012) Iron oxide nano-particlesimmobilized-sand material in the treatment of $\mathrm{Cu}$ (II), $\mathrm{Cd}$ (II) and $\mathrm{Pb}$ (II) contaminated waste waters. Chem Eng J 195: 103-111.

134. Unob F, Wongsiri B, Phaeon N, Puanngama M, Shiowatana J (2007) Reuse of waste silica as adsorbent for metal removal by iron oxide modification. J Hazard Mater 142: 455-462.

135. Huang Y, Hsueh C, Huang C, Su L, Chen C (2007) Adsorption thermodynamic and kinetic studies of $\mathrm{Pb}$ (II) removal from water onto a versatile Al2O3-supported iron oxide. Sep Purif Technol 55: 23-29.

136. Rui X, Wang Y, Zhang X, Lu C (2014) Facile synthesis of magnetic nanocomposites of cellulose@ultrasmall iron oxide nanoparticles for water treatment. R soc Chem Adv 4: 226-232.

137. Otto M, Floyd M, Bajpai S (2008) Nanotechnology for site remediation. Remed J 9: 99-108.

138. Kim Y, Lee B, Yi J (2003) Preparation of functionalized mesostructured silica containing magnetite (MSM) for the removal of copper ions in aqueous solutions and its magnetic separation. Sep Sci Technol 38: 2533-2548.

139. Wang Y, Zou B, Gao T, Wu X, Lou S, et al. (2012) Synthesis of orange-like $\mathrm{Fe} 3 \mathrm{O} 4 / \mathrm{PPy}$ composite microspheres and their excellent $\mathrm{Cr}(\mathrm{VI})$ ion removal properties. Journal of Materials Chemistry 22: 9034-9040.

140. Barnett MO, Jardine PM, Brooks SC, Selim HM (2000) Adsorption and transport of uranium(VI) in subsurface media. Soil Sci Soc Am J 64: 908-917.

141. WHO (2005) Uranium in drinking water. Background document for the development of WHO guidelines for drinking water quality.

142. Zamora ML, Zielinski JM, Meyerhof DP, Moss MA (1998) Chronic ingestion of uranium in drinking water: a study of kidney bioeffects in humans. Toxicol Sci 43: 68- 77.

143. Bargar JR, Reitmeyer R, Lenhart JJ, Davis JA (2000) Characterization of $\mathrm{U}(\mathrm{VI})$ carbonato ternary complexes on heamatite: EXAFS and electrophoretic mobility measurements. Geochim Cosmochim Acta 64: 2737-2749.

144. Duff MC, Amrhein C (1996) Uranium(VI) adsorption on goethite and soil in carbonate solutions. Soil Sci Soc Am J 60: 1393-1400.

145. Waite TD, Davis JA, Payne TE, Waychunas GA, Xu N (1994) Uranium(VI) adsorption to ferrihydrite: Application of a surface complexation model. Geochim Cosmochim Acta 58: 5465-5478.

146. Katsoyiannis IA, Althoff HW, Bartel H, Jekel M (2006) The effect of groundwater composition on uranium(VI) sorption onto bacteriogenic iron oxides. Water Res 40: 3646-3652.

147. Katsoyiannis IA (2007) Carbonate effects and pH-dependence of uranium sorption onto bacteriogenic iron oxides: Kinetic and equilibrium studies. J Hazard Mater 139: 31-37.

148. Barnett MO, Jardine PM, Brooks SC (2002) U(VI) adsorption to heterogeneous subsurface media: application of surface complexation model. Environ Sci Technol 36: 937-942.

149. Wazne M, Korfiatis GP, Meng X (2003) Carbonate effects on hexavalent uranium adsorption by iron oxyhydroxides. Environ Sci Technol 37: 3619-3624.

150. Herman DS, Geraldine M, Venkatesh T (2007) Evaluation, diagnosis, and treatment of lead poisoning in a patient with occupational lead exposure: a case presentation. J Occup Med Toxicol 24: 7.

151. Liu X, Hu Q, Fang Z, Zhang X, Zhang B (2009) Magnetic chitosan nanocomposites: a useful recyclable tool for heavy metal ion removal. Langmuir 25: 3-8.

152. Lee S, Laldawngliana C, Tiwari D (2012) Iron oxide nano-particlesimmobilized-sand material in the treatment of $\mathrm{Cu}$ (II), $\mathrm{Cd}$ (II) and $\mathrm{Pb}$ (II) contaminated waste waters. Chem Eng J 195-103-111.

153. Unob F, Wongsiri B, Phaeon N, Puanngama M, Shiowatana J (2007) Reuse of waste silica as adsorbent for metal removal by iron oxide modification. J Hazard Mater 142: 455-462.

154. Huang Y, Hsueh C, Huang C, Su L, Chen C (2007) Adsorption thermodynamic and kinetic studies of $\mathrm{Pb}$ (II) removal from water onto a versatile Al 2 O 3-supported iron oxide. Sep Purif Technol 55: 23-29. 
155. Rui X, Wang Y, Zhang X, Lu C, (2014) Facile synthesis of magnetic nanocomposites of cellulose@ultrasmall iron oxide nanoparticles for water treatment. R soc Chem Advance 4: 226-232.

156. Otto M, Floyd M, Bajpai S (2008) Nanotechnology for site remediation. Remed J 9: 99-108.

157. Kim Y, Lee B, Yi J (2003) Preparation of functionalized mesostructured silica containing magnetite (MSM) for the removal of copper ions in aqueous solutions and its magnetic separation. Sep Sci Technol 38: 2533-2548.

158. Pomati F, Castiglioni S, Zuccato E, Fanelli R, Vigetti D, et al. (2006) Effects of a complex mixture of therapeutic drugs at environmental levels on human embryonic cells. Environ Sci Technol 40: 2442-2447.

159. Kim Y, Choi K, Jung JY, Park S, Kim PG, et al. (2007) Aquatic toxicity of acetaminophen carbamazepine cimetidine diltiazem and six major sulfonamides and their potential ecological risks in Korea. Environ Int 33: 370-375.

160. Kolok AS, Snow DD, Kohno S, Sellin MK, Guillette LJ (2007) Occurrence and biological effect of exogenous steroids in the Elkhorn River Nebraska USA. Sci Total Environ 388: 104-115.

161. Lyssimachou A, Arukwe A (2007) Alteration of brain and interrenal StAR protein P450scc and Cyp11 beta mRNA levels in Atlantic salmon after nominal waterborne exposure to the synthetic pharmaceutical estrogen ethynylestradiol. J Toxicol Environ Health Part A 70: 606-613.

162. Lai HT, Hou JH, Su CI, Chen CL (2009) Effects of chloramphenicol florfenicol and thiamphenicol on growth of algae Chlorella pyrenoidosa Isochrysis galbana and Tetraselmis chui. Ecotoxicol. Environ Saf 72 329-334.

163. Carlsson B, Johansson AK, Alvan G, Kuhler T (2006) Are pharmaceuticals potent environmental pollutants? Part I: Environmental risk assessments of selected active pharmaceutical ingredients. Sci Total Environ 364: 67-87.

164. Hao C, Lissemore L, Nguyen B, Kleywegt S, Yang P, et al. (2006) Determination of pharmaceuticals in environmental waters by liquid chromatography/electrospray ionization/tandem mass spectrometry. Anal Bioanal Chem 384: 505-513.

165. Lin AYC, Plumlee MH, Reinhard M (2006) Natural attenuation of pharmaceuticals and alkylphenol polyethoxylate metabolites during river transport: Photochemical and biological transformation. Environ Toxicol Chem 25: 1458-1464.

166. Xu WH, Zhang G, Zou SC, Li XD, Liu YC (2007) Determination of selected antibiotics in the Victoria Harbour and the Pearl River South China using high performance liquid chromatography- electrospray ionization tandem mass spectrometry. Environ Pollut 145: 672-679.

167. Pedrouzo M, Reverte S, Borrull F, Pocurull E, Marce RM (2007) Pharmaceutical determination in surface and wastewaters using high performance liquid chromatography-(electrospray)-mass spectrometry. J Sep Sci 30: 297-303.

168. Zhang SY, Zhang QA, Darisaw S, Ehie O, Wang GD (2007) Simultaneous quantification of polycyclic aromatic hydrocarbons (PAHs) polychlorinated biphenyls (PCBs) and pharmaceuticals and personal care products (PPCPs) in Mississippi river water in New Orleans Louisiana USA. Chemosphere 66: 1057-1069.

169. Santos JL, Aparicio I, Callejon M, Alonso E (2009) Occurrence of pharmaceutically active compounds during 1 -year period in wastewaters from four wastewater treatment plants in Seville (Spain). J Hazard Mater 164: $1509-1516$.

170. Nakada N, Kiri K, Shinohara H, Harada A, Kuroda K, et al. (2008) Evaluation of pharmaceuticals and personal care products as watersoluble molecular markers of sewage. Environ Sci Technol 42: 6347-6353.

171. Stulten D, Zuhlke S, Lamshoft M, Spiteller M (2008) Occurrence of diclofenac and selected metabolites in sewage effluents. Sci Total Environ 405: 310-316.

172. Chang H, Hu JY, Wang LZ, Shao B (2008) Occurrence of sulfonamide antibiotics in sewage treatment plants. Chin Sci Bull 53: 514-520.

173. Latham AH, Williams ME (2008) Controlling transport and chemical functionality of magnetic nanoparticles. Acc Chem Res 41: 411-420.
174. Toprak MS, Mc Kenna BJ, Mikhaylova M, Waite JH, Stucky GD (2007) Spontaneous assembly of magnetic microspheres. Adv Mater 19: 1362-1368.

175. Ambashta RD, Sillanpaa M (2010) Water purification using magnetic assistance: A review. J Hazard Mater 180: 38-49.

176. Yavuz CT, Mayo JT, Yu WW, Prakash A, Falkner JC, et al. (2006) Lowfield magnetic separation of monodisperse $\mathrm{Fe} 3 \mathrm{O} 4$ nanocrystals. Science 314: 964-967.

177. Shannon MA, Bohn PW, Elimelech M, Georgiadis JG, Marinas BJ, et al. (2008) Science and technology for water purification in the coming decades. Nature 452: 301-310.

178. Zhihui AI, Cheng Y, Zhang LZ, Qiu JR (2008) Efficient removal of Cr(VI) from aqueous solution with $\mathrm{Fe} @ \mathrm{Fe} 2 \mathrm{O} 3$ core-shell nanowires. Environ Sci Technol 42: 6955-6960.

179. Tuutijarvi T, Lu J, Sillanpaa M, Chen G (2009) As(V) adsorption on maghemite nanoparticles. J Hazard Mater 166: 1415-1420.

180. Yantasee W, Warner CL, Sangvanich T, Addleman RS, Carter TG, et al. (2007) Removal of heavy metals from aqueous systems with thiol functionalized superparamagnetic nanoparticles. Environ Sci Technol 41: 5114-5119.

181. Iram M, Guo C, Guan YP, Ishfaq A, Liu HZ (2010) Adsorption and magnetic removal of neutral red dye from aqueous solution using $\mathrm{Fe} 3 \mathrm{O} 4$ hollow nanospheres. J Hazard Mater 181: 1039-1050.

182. Ma ZY, Guan YP, Liu XQ, Liu HZ (2005) Preparation and characterization of micronlsized nonlporous magnetic polymer microspheres with immobilized metal affinity ligands by modified suspension polymerization. J Appl Polym Sci 96: 2174-2180.

183. Wang P, Shi QH, Shi YF, Clark K, Stucky GD, et al. (2009) Magnetic permanently confined micelle arrays for treating hydrophobic organic compound contamination. J. Am. Chem. Soc 131: 182-188.

184. Wang HT, Keller AA, Clark K (2011) Natural organic matter removal by adsorption onto magnetic permanently confined micelle arrays. J. Hazard. Mater 194: 156-161.

185. Clark KK, Keller AA (2012) Adsorption of perchlorate and other oxyanions onto magnetic permanently confined micelle arrays (MagPCMAs). Water Res 46: 635-644.

186. Akhavan O, Azimirad R (2009) Photocatalytic property of $\mathrm{Fe} 2 \mathrm{O} 3$ nanograin chains coated by $\mathrm{TiO} 2$ nanolayer in visible light irradiation. Appl Catal A Gen 369: 77-82.

187. Bandara J, Klehm U, Kiwi J (2007) Raschig rings-Fe2O3 composite photocatalyst activate in the degradation of 4-chlorophenol and Orange II under daylight irradiation. Appl CatalB Environ 76: 73-81.

188. Wu F, Sheng DN, Hua HL (2000) Degradation mechanism of azo dye CI reactive red 2 by iron powder reduction and photooxidation in aqueous solutions. Chemosphere 41: 1233-1238.

189. Khedr M, Abdelhalim K, Soliman N (2009) Synthesis and photocatalytic activity of nanosized iron oxides. Mater Lett 63: 598-601.

190. Otto M, Floyd M, Bajpai S (2008) Nanotechnology for site remediation. Remed J 19: 99-108.

191. Zhang XW, Lei LC (2008) Preparation of photocatalytic Fe2O3-TiO2 coatings in one step by metal organic chemical vapor deposition. Appl Surf Sci 254: 2406-2412.

192. Akhavan O, Azimirad R (2009) Photocatalytic property of $\mathrm{Fe} 2 \mathrm{O} 3$ nanograin chains coated by $\mathrm{TiO} 2$ nanolayer in visible light irradiation. Appl Catal A Gen 369: 77-82.

193. Peng LL, Xie TF, Lu YC, Fan HM, Wang DJ (2010) Synthesis, photoelectric properties and photocatalytic activity of the $\mathrm{Fe} 2 \mathrm{O} 3 / \mathrm{TiO} 2$ heterogeneous photocatalysts. Chem Phys 12: 8033-8041.

194. Shinde S, Bhosale C, Rajpure K (2011) Photocatalytic oxidation of salicylic acid and 4- chlorophenol in aqueous solutions mediated by modified AlFe2O3 catalyst under sunlight. J Mol Catal A 347: 65-72.

195. Lei J, Liu CS, Li FB, Li XM, Zhou SG, Liu TX, et al. (2006) Photodegradation of orange I in the heterogeneous iron oxide-oxalate complex system under UVA irradiation. J Hazard Mater 137: 1016-1024. 
Citation: Namdeo M (2017) Magnetite Nanoparticles as Effective Adsorbent for Water Purification-A Review. Adv Recycling Waste Manag 2: 135. doi:10.4172/2475-7675.1000135

196. Leland JK, Bard AJ (1987) Photochemistry of colloidal semiconducting iron oxide polymorphs. J Chem Phys 91: 5076-5083. 